\title{
BIOESTIMULANTE E FERTILIZANTE ASSOCIADOS AO TRATAMENTO DE SEMENTES DE MILHO ${ }^{1}$
}

\author{
LEIDIANEAPARECIDAFERREIRA ${ }^{2}$, JOÃOALMIR OLIVEIRA ${ }^{3}$, ÉDILAVILELADERESENDE VONPINHO ${ }^{4}$, DANILO LUIZDE QUEIROZ $^{5}$
}

RESUMO - O cultivo do milho é altamente tecnológico e absorve as inovações no sistema produtivo, visando ganhos em produção, mas deve-se atentar para os reais ganhos com a incorporação de novos produtos às sementes. $\mathrm{O}$ objetivo deste trabalho foi avaliar o efeito do bioestimulante Stimulate ${ }^{\circledR}$ e do fertilizante líquido Cellerate ${ }^{\circledR}$, via tratamento de sementes, seis meses antes da semeadura e na pré-semeadura, na qualidade fisiológica das sementes de um híbrido simples (GNZ 2004) e de uma linhagem (L57) e na produtividade da cultura. Os ensaios foram conduzidos no Laboratório de Sementes e no campo experimental da Universidade Federal de Lavras (UFLA), Lavras/Mg. Os tratamentos, nas duas épocas, foram: testemunha; $5 \mathrm{~mL} . \mathrm{kg}^{-1}$ de sementes de Stimulate ${ }^{\circledR} 5$ e 10 mL.kg ${ }^{-1}$ de sementes de Cellerate ${ }^{\circledR}$. Para avaliação da qualidade das sementes foram realizados os teste de germinação, emergência, velocidade de emergência, teste de frio, massa seca de parte aérea e de raiz das plântulas e análise das enzimas esterase, superóxido dismutase, malato desidrogenase, álcool desidrogenase, catalase e á-amilase. No ensaio em campo foram avaliadas a altura de planta, altura de espiga, número de espigas e produtividade. O tratamento das sementes de milho com o Cellerate ${ }^{\circledR}$, na dose de $10 \mathrm{ml} \cdot \mathrm{kg}^{-1}$ de sementes, acima da dose recomendada pelo fabricante, reduz a emergência de plântulas de milho de linhagem e de híbrido e a germinação de sementes de linhagem, quando o tratamento é feito na pré-semeadura. O tratamento das sementes de milho com o bioestimulante Stimulate ${ }^{\circledR}$ e com o fertilizante Cellerate ${ }^{\circledR}$ não afeta a produtividade de grãos.

Termos para indexação: Zea mays, regulador de crescimento, zinco, molibdênio.

\section{TREATMENT OF CORN SEEDS WITH BIOSTIMULANT AND FERTILIZER}

\begin{abstract}
The corn crop is very technological and this productive system absorbs all possible innovations to improve the yield, nevertheless some care should be taken concerning the addition of new chemicals to the seeds. The objective of this study was to evaluate the effect of seed treatment, with the biostimulant Stimulate ${ }^{\circledR}$ as well with the liquid fertilizer Cellerate ${ }^{\circledR}$ at 6 months before sowing and in the pre- sowing, on the physiological quality of seeds, on corn yield. Experiments were performed at the Federal University of Lavras, MG, Brazil in 2005, at field and laboratory level with a corn hybrid (GNZ 2004) and with a corn line (L57). The treatments used for corn assays were: witness (without chemicals); $5 \mathrm{~mL} \cdot \mathrm{kg}^{-1}$ Stimulate ${ }^{\circledR} ; 5$ and $10 \mathrm{~mL} \cdot \mathrm{kg}^{-1}$ Cellerate${ }^{\circledR}$. The seed physiological quality was accessed by germination, EVI, cold test and above and under ground dry mass of plantlets and by the analysis of the enzymes esterase, superoxide dismutase, malate dehydrogenase, alcohol dehydrogenase, catalase and á-amylase. The laboratory experiments were carried out in a complete randomized design with four replications. The a randomized block design was used of hybrid and line corn field with four replicates in a $4 \times 2$ factorial with the time and the compounds for seed treatment being the factors. In this assay plant and spike height, number
\end{abstract}

\footnotetext{
${ }^{1}$ Submetido em 14/07/2006. Aceito para publicação em 01/03/2007. Parte da Dissertação de Mestrado do primeiro autor, apresentada à UFLA.

${ }^{2}$ Eng. Agrônoma, Mestranda em Agronomia, Dep. de Agricultura/Setor de Sementes, UFLA(Universidade Federal de Lavras), C. P. 37, CEP $37200-$
} 000, Lavras-MG, lafufla@yahoo.com.br.

\footnotetext{
${ }^{3}$ Eng. Agrônomo, Prof. Titular do Dep. de Agricultura/Setor de Sementes, UFLA, C. P. 37, CEP 37 200-000, Lavras-MG, jalmir@ufla.br.

${ }^{4}$ Eng. Agrônoma, Profa. Titular do Dep. de Agricultura/Setor de Sementes, UFLA, C. P. 37, CEP 37 200-000, Lavras-MG, edila@ufla.br.

${ }^{5}$ Eng. Agrônomo, Emater/MG, dlqueirozagronomia@yahoo.com.br.
} 
of spikes per plant and productivity were evaluated. Corn seeds treated with Stimulate ${ }^{\circledR}$ and Cellerate ${ }^{\circledR}$ promoted greater plantlet development in the line and of roots in the hybrid. A high concentration of Cellerate ${ }^{\circledR}$ seems to reduce hybrid emergence and germination as well as the emergence of the line seeds when they have been treated at the pre-sowing stage. An increase was observed in the activity of the enzymes malato dehydrogenase and catalase in the hybrid seeds treated with the high concentration of Cellerate ${ }^{\circledR}$ in the pre-sowing and 6 months before sowing, respectively. However, the line seeds when treated with high concentrations of Cellerate ${ }^{\circledR}$ in the pre-sowing stage showed a reduction in malate dehydrogenase activity and increase in alcohol dehydrogenase activity. The activity of á-amylase was higher in the hybrid seeds treated with Stimulate ${ }^{\circledR}$ before the storage and with dosage 1 of Cellerate ${ }^{\circledR}$ in the pre-sowing and the lineage seeds presented greater á-amylase activity when treated with Stimulate ${ }^{\circledR}$ at pre-sowing. The corn yield was not affected by the treatments.

Index terms: Zea mays, growth regulator, zinc, molibdenium.

\section{INTRODUÇÃO}

O surgimento de novos produtos para a incorporação de aditivos às sementes aumenta a cada ano. No entanto, pouco se sabe sobre o real efeito desses produtos a base de hormônios, micronutrientes, aminoácidos e vitaminas na qualidade fisiológica das sementes e na produtividade das culturas.

Cultivos tecnológicos como o milho, absorvem enormemente inovações no sistema produtivo, mas deve-se atentar para os reais ganhos com a incorporação desses produtos às sementes, que são o principal insumo da agricultura moderna, pois são responsáveis por todo o potencial genético e produtivo que garantem o sucesso do empreendimento agrícola.

Os bioestimulantes são complexos que promovem o equilíbrio hormonal das plantas, favorecendo a expressão do seu potencial genético, estimulando o desenvolvimento do sistema radicular (Ono et al., 1999). Esses produtos agem na degradação de substâncias de reserva das sementes, na diferenciação, divisão e alongamento celulares (Castro e Vieira, 2001).

Os resultados de pesquisas são contraditórios. A utilização do bioestimulante Stimulate ${ }^{\circledR}$ em sementes de algodão não afetou a germinação e emergência de plântulas (Belmonte et al., 2003). Já sua utilização em feijão, soja e arroz apresentou efeito positivo (Vieira, 2001; Alleoni, 1997 e Vieira e Castro, 2000). No entanto, Dário e Baltiere (1998) não observaram diferenças significativas quando trataram sementes de milho com o bioestimulante.

A aplicação de giberelina em plantas de milho na fase vegetativa resulta em maior desenvolvimento da parte aérea, sem afetar a produção de massa seca e rendimento dos grãos (Castro e Kluge, 1999).

Assim como os bioestimulantes, a resposta à aplicação de micronutrientes também é muito variável. Mas o aumento da produtividade e, por conseqüência, a diminuição do custo relativo tem motivado produtores a utilizá-los, principalmente para as culturas do milho e da soja.

O molibdênio exerce papel indispensável na assimilação do nitrato absorvido pelas plantas, atuando ao nível da redutase do nitrato. Portanto, qualquer deficiência do elemento pode comprometer o metabolismo do nitrogênio, diminuindo o rendimento das culturas. O micronutriente mais limitante à produção da cultura do milho é o zinco e o que geralmente apresenta maiores problemas de deficiência nos solos brasileiros.

Os resultados de pesquisa com o tratamento de sementes com bioestimulantes e micronutrientes são os mais diversos possíveis. Desse modo, neste trabalho foram avaliados o efeito do bioestimulante, Stimulate ${ }^{\circledR}(0,009 \%$ de cinetina, 0,005\% de auxina e 0,005\% de ácido giberélico), e do fertilizante líquido, Cellerate ${ }^{\circledR}(10 \%$ de Mo e $5 \%$ de $\mathrm{Zn})$, em tratamento de sementes, realizado seis meses antes da semeadura e na pré-semeadura, na qualidade fisiológica de sementes de milho e na produtividade de grãos.

\section{MATERIALE MÉTODOS}

O trabalho foi conduzido no Laboratório de Análises de Sementes e na área experimental do Departamento de Agricultura da Universidade Federal de Lavras (UFLA), em Lavras, MG. Foram utilizadas sementes de milho de híbrido simples (GNZ 2004) e de uma linhagem (L57), provenientes da empresa Gene Seeds Recursos Genéticos em Milho. 
As sementes de milho foram tratadas com fungicida Tegran ${ }^{\circledR}$ na dosagem de $250 \mathrm{~g} / 100 \mathrm{Kg}$ de sementes e inseticida K-obiol ${ }^{\circledR}$ na dosagem recomendada pelo fabricante; os produtos químicos antes de serem incorporados às sementes foram associados com polímero Disco Agro Red L203, na dosagem de $3 \mathrm{~mL} . \mathrm{kg}^{-1}$ de sementes, fornecido pela INCOTEC. Parte das sementes de milho foi tratada com $15 \mathrm{~mL} . \mathrm{Kg}^{-1}$ de sementes do bioestimulante Stimulate ${ }^{\circledR}$ (0,009\% de cinetina, 0,005\% de auxina e $0,005 \%$ de ácido giberélico) e parte com 5 e 10 mL.Kg ${ }^{-1}$ de sementes do fertilizante Cellerate ${ }^{\circledR}(10 \%$ de Mo e $5 \%$ de Zn), e armazenadas por seis meses. Na outra parte das sementes armazenadas, o tratamento com os produtos foi realizado na pré-semeadura. As sementes de cada tratamento foram distribuídas em embalagens distintas de papel multifoliado, para as avaliações na pré-semeadura, após o armazenamento por seis meses na Usina de Beneficiamento da UFLA. A umidade relativa do ar e a temperatura foram monitoradas por meio de um termohigrógrafo instalado no local (Figura 1). As sementes tratadas seis meses antes da semeadura e na pré-semeadura foram submetidas à avaliação da qualidade fisiológica e às avaliações agronômicas em dois ensaios descritos a seguir.

\section{Análise da qualidade de sementes}

Teste de germinação: a semeadura foi feita em folhas de papel germitest, pelo sistema de rolos umedecidos com água, em quantidade equivalente a 2,5 vezes a massa do substrato seco. Os rolos foram colocados em germinadores à temperatura de $25^{\circ} \mathrm{C}$. Aos 4 e 7 dias, foram realizadas as contagens do número de plântulas normais, segundo os critérios das Regras para Análise de Sementes-RAS (Brasil, 1992). Cada tratamento foi composto de 4 repetições com 50 sementes. Os resultados foram expressos em porcentagem de plântulas normais.

Teste de frio: a semeadura foi realizada em bandejas plásticas contendo substrato composto por areia + terra na proporção de 2:1, sendo a terra proveniente da área experimental da UFLA cultivada com milho. De acordo com as prescrições da "International Seed Test Association" (ISTA, 1995), a umidade do substrato foi ajustada para 70\% da sua capacidade de retenção. Cada tratamento foi composto por 4 repetições de 50 sementes. Após a semeadura, as bandejas foram colocadas em câmara fria a $10^{\circ} \mathrm{C}$ por 7 dias. Posteriormente, foram transferidas para câmara de crescimento vegetal à temperatura de $25^{\circ} \mathrm{C}$, em regime alternado de luz e escuro (12 horas), onde permaneceram por mais 7 dias, quando foi avaliado o número de plântulas normais emersas.

Testes de emergência e de velocidade de emergência de plântulas: a semeadura foi realizada em bandejas plásticas contendo substrato composto por terra + areia na proporção de 1:2. A umidade do substrato foi ajustada para $70 \%$ da sua capacidade de retenção. Cada tratamento foi composto por 4 repetições de 50 sementes. Após a semeadura, as bandejas foram mantidas em câmara de crescimento a $25^{\circ} \mathrm{C}$, em regime alternado de luz e escuro (12 horas). Foram realizadas avaliações diárias a partir do início da emergência,

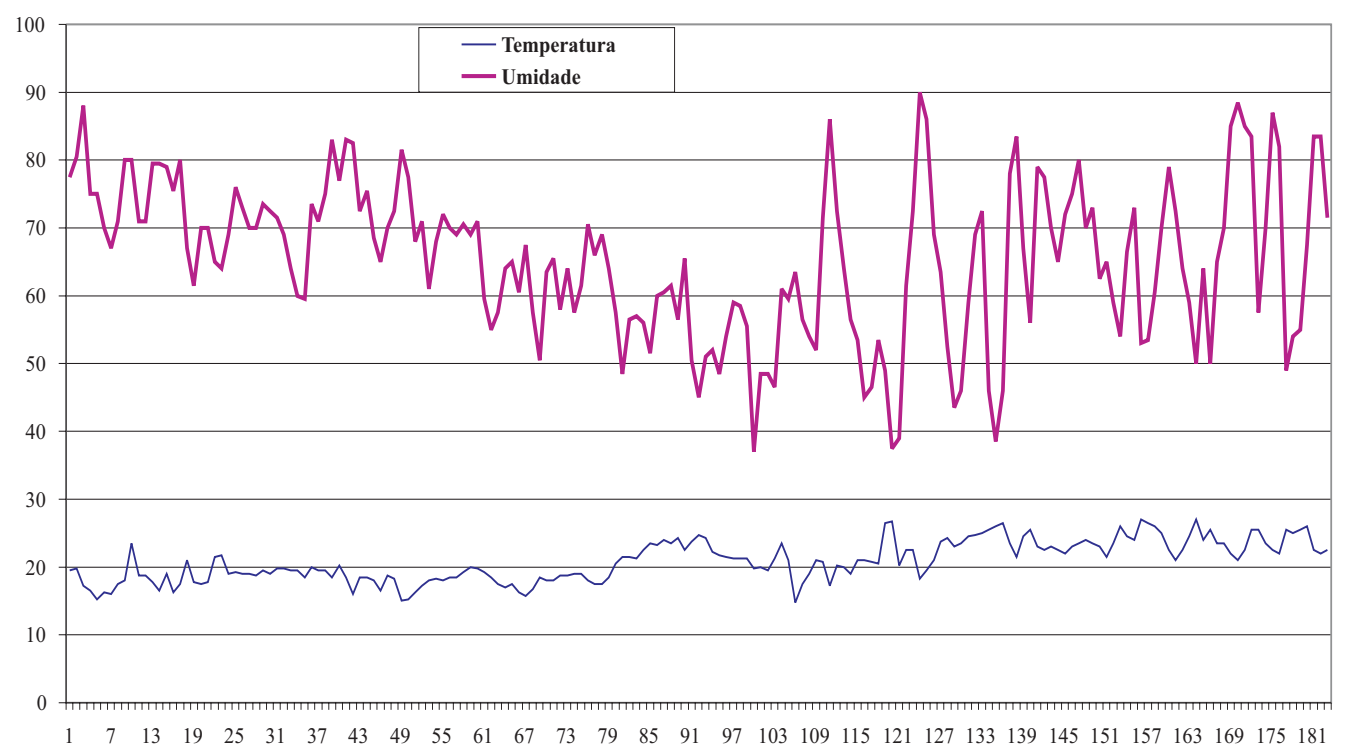

FIGURA 1. Variação diária das médias de temperatura, em ${ }^{\circ} \mathrm{C}$, e de umidade relativa do ar, em \%, registradas no período de junho a novembro do ano de 2005, na Usina de Beneficiamento de Sementes da UFLA. UFLA, Lavras, MG, 2006. 
computando-se o número de plântulas emersas até a estabilização. Foram computadas a porcentagem de plântulas emersas aos 14 dias e o índice de velocidade de emergência, segundo a fórmula proposta por Maguire (1962).

Massa seca de Parte aérea e de raiz: para o cálculo da massa seca de parte aérea e de raiz, foram utilizadas as plântulas do teste de emergência em bandeja. Aos 14 dias, as plântulas foram separadas em parte aérea e raiz. A parte aérea das plântulas de milho foi acondicionada em sacos de papel, e levada à estufa com circulação forçada de ar, regulada a temperatura de $65^{\circ} \mathrm{C}$, até o material atingir massa constante. As raízes foram arrancadas e lavadas com água corrente; em seguida foram acondicionadas em sacos de papel e levadas à estufa nas mesmas condições já citadas. Desse modo, foram calculadas as massas secas de parte aérea e de raiz, sendo os resultados expressos em gramas por planta.

Análise de enzimas: quatro amostras de 25 sementes de cada tratamento foram semeadas em folha de papel germitest, pelo sistema de rolos umedecidos com água, em quantidade equivalente a 2,5 vezes a massa do substrato seco e os rolos foram colocados em germinadores à temperatura de $25^{\circ} \mathrm{C}$ por 48 e 70 horas. Após esse período, duas amostras de 25 sementes germinadas por 48 horas e duas, germinadas por 70 horas, de cada tratamento, foram maceradas em mortar com utilização de nitrogênio líquido e antioxidante PVP (Polivinil Pirrolidone) e conservadas em freezer a $-80^{\circ} \mathrm{C}$ até a realização das análises. Foram retiradas subamostras de $100 \mathrm{mg}$, nas quais se adicionou o tampão de extração (Tris $\mathrm{HCl}$ 0,2 M pH 8) na quantidade de 2,5 vezes a massa de cada amostra e 0,1\% de â-mercaptoetanol; em seguida as amostras foram agitadas em vortex por 1 minuto. O material foi colocado em geladeira “over night” e depois foi centrifugado a $14000 \mathrm{rpm}$ por 30 minutos a $4^{\circ} \mathrm{C}$. Foram aplicados $60 \mu \mathrm{L}$ do sobrenadante no gel de corrida (gel separador - poliacrilamida 7,5\% e gel concentrador - poliacrilamida 4,5\%) e gel de amido para o sistema enzimático á-amilase (gel separador - poliacrilamida 7,5\% e amido solúvel 0,5\% e gel concentrador - poliacrilamida 4,5\%). O sistema tampão gel/eletrodo utilizado foi a Trisglicina $\mathrm{pH} 8,9$. As corridas foram efetuadas a $150 \mathrm{~V}$ por 4,2 horas. Após a eletroforese, procedeu-se à revelação das enzimas esterase (EST), superóxido dismutase (SOD), malato desidrogenase (MDH), álcool desidrogenase (ADH), catalase (CAT) e á-amilase (á-AM) (Alfenas, 1991).

O delineamento experimental utilizado foi o inteiramente casualizado, em esquema fatorial $4 \times 2$, sendo os fatores: produtos (Stimulate ${ }^{\circledR}$, Dose 1 de Cellerate ${ }^{\circledR}$, Dose 2 de Cellerate $^{\circledR}$ e sem tratamento) e período de tratamento das sementes (6 meses antes da semeadura e pré-semeadura). Foi realizada a análise de variância utilizando o programa estatístico Sisvar (Ferreira, 2000). Para a comparação entre as médias, empregou-se o Teste de Tukey a 5\% de probabilidade. A avaliação dos padrões enzimáticos foi feita de acordo com a intensidade das bandas, utilizando-se a superfície de um diafanoscópio.

\section{Experimento em campo}

O ensaio de milho foi conduzido na área experimental do Departamento de Agricultura da Universidade Federal de Lavras, em área com latossolo vermelho-escuro (LE), textura argilosa, cujas características químicas foram analisadas via análise de solo.

As sementes do híbrido e da linhagem de milho tratadas antes do armazenamento (6 meses) com o bioestimulante e micronutrientes foram pesadas e separadas. Parte das sementes recebeu os produtos Stimulate ${ }^{\circledR}$ e Cellerate ${ }^{\circledR}$ nas mesmas dosagens, na pré-semeadura, e ficaram em bandejas, à sombra, até a secagem; em seguida, procedeu-se a semeadura no campo.

O solo foi preparado convencionalmente e as correções foram feitas de acordo com a análise química do mesmo. A semeadura foi realizada na segunda quinzena do mês de novembro de 2005. Cada parcela foi constituída de 4 linhas de $5 \mathrm{~m}$ de comprimento, espaçadas $0,8 \mathrm{~m}$ entre linhas, sendo considerada como área útil as duas linhas centrais. Foram distribuídas 10 sementes por metro linear, realizando-se o desbaste 30 dias após a semeadura, deixando-se 6 plantas por metro linear.

A adubação de base foi feita com 400 kg.ha-1 de NPK 828-16. A adubação de cobertura foi realizada de acordo com o manejo convencional da cultura; foram aplicados $300 \mathrm{~kg}$.ha${ }^{1}$ de NPK 30-0-20. Os tratos culturais e controle de formigas foram realizados quando necessários.

Foram avaliadas as seguintes características:

Estande final: contagem do número de plantas existentes

TABELA 1. Porcentagem de emergência, em teste de frio, de plântulas de híbrido de milho oriundas de sementes tratadas com diferentes produtos. UFLA, Lavras, MG, 2006.

\begin{tabular}{lc}
\hline Produtos & Emergência \\
\hline Testemunha $^{\circledR}$ & $90,5 \mathrm{~A}$ \\
Stimulate $^{(}$ & $86,0 \mathrm{AB}$ \\
Cellerate 1 & $83,8 \mathrm{AB}$ \\
Cellerate 2 & $81,0 \mathrm{~B}$ \\
\hline
\end{tabular}

As médias seguidas pela mesma letra não diferem entre si, pelo Teste de Tukey, a 5\% de probabilidade. 
em cada parcela por ocasião da colheita;

Altura de planta: altura média de 10 plantas competitivas de cada parcela útil, medidas em metros, do nível do solo até o ponto de inserção da folha bandeira. Foi realizada antes da colheita;

Altura de espiga: altura média das espigas de 10 plantas competitivas da parcela útil, medidas em metros, do nível do solo até o ponto de inserção da espiga superior;

Número de espigas: foi realizada a contagem do número total de espigas em cada parcela útil;

Produtividade: após a colheita manual, as espigas foram despalhadas e debulhadas; determinou-se o teor de água dos grãos e foi feita a correção para $13 \%$ e os dados foram transformados em Kg.ha-1.

Os ensaios foram instalados em blocos casualizados (DBC) com quatro repetições, em esquema fatorial 4x2, sendo os fatores: produtos (Stimulate ${ }^{\circledR}$, Dose 1 de Cellerate ${ }^{\circledR}$, Dose 2 de Cellerate ${ }^{\circledR}$ e sem tratamento) e período de tratamento das sementes (6 meses antes da semeadura e pré-semeadura).

Os dados obtidos foram analisados pelo programa Sisvar (Ferreira, 2000). As médias entre os tratamentos foram comparadas pelo Teste de Tukey, a 5\% de probabilidade.

\section{RESULTADOS E DISCUSSÃO}

\section{Avaliação da qualidade fisiológica das sementes do híbrido de milho}

Pelos resultados da análise de variância houve diferença significativa $(\mathrm{p}<0,05)$, pelo teste de $\mathrm{F}$, para os parâmetros emergência pelo teste de frio, índice de velocidade de emergência e massa seca de raiz das plântulas, em relação ao fator produtos; e para massa seca de parte aérea, em relação à época de aplicação.

A emergência das plântulas em condição de estresse, pelo teste de frio, foi afetada pelo Cellerate ${ }^{\circledR} 2$, na dosagem de 10 $\mathrm{mL} . \mathrm{kg}^{-1}$ de sementes, reduzindo a emergência em relação à testemunha (Tabela 1). Provavelmente esse produto, nessa dosagem, tenha causado algum efeito fitotóxico durante o período em que as sementes ficaram expostas à condição de baixa temperatura, pois sob condições normais do teste de germinação, este efeito não foi verificado. No entanto, não houve diferença nos valores de emergência quando as sementes foram tratadas com o Stimulate ${ }^{\circledR}$ e com as duas doses de Cellerate ${ }^{\circledR}$.

Já pelos resultados de massa seca de raízes, observa-se que o Cellerate ${ }^{\circledR}$ na dose mais alta (10 mL. $\mathrm{kg}^{-1}$ de sementes) promoveu um maior acúmulo de matéria seca em relação à testemunha (Tabela 2), comprovando o efeito desses produtos sobre o maior desenvolvimento radicular das plantas. Resultados semelhantes foram encontrados por Vieira (2001) e Vieira e Castro (2000).

Pelos resultados da Tabela 3 , observa-se que a massa seca de parte aérea das plântulas foi maior quando as sementes foram tratadas antes do armazenamento (6 meses antes da semeadura).

Avaliação dos padrões enzimáticos das sementes do híbrido de milho

Observa-se, pela análise dos padrões enzimáticos de sementes do híbrido de milho revelados para a malato desidrogenase (MDH), uma menor atividade da enzima nas sementes tratadas com a dose mais alta de Cellerate ${ }^{\circledR}$, seis meses antes da semeadura, comparado aos padrões da testemunha e aos das tratadas na pré-semeadura, indicando menor atividade respiratória nessa condição (Figura 2). A enzima malato desidrogenase catalisa a conversão de malato a oxalacetato, tendo uma importante função dentro do ciclo de Krebs, além de participar do movimento de malato através da membrana mitocondrial e da fixação de $\mathrm{CO}_{2}$ nas plantas (Taiz e Zeiger, 1991). Quando a via aeróbica é comprometida, a via anaeróbica da respiração é ativada e produtos tóxicos às células como acetaldeído e etanol são acumulados. No metabolismo anaeróbico, o piruvato, primariamente produzido na glicólise, é convertido para acetaldeído pela ação da enzima piruvato descarboxilase e o acetaldeído é, então, reduzido para etanol pela álcool desidrogenase (ADH). No entanto não foram verificadas diferenças nos padrões da ADH para essas

TABELA2. Massa seca de raiz (MSR) de plântulas de híbrido de milho oriundas de sementes tratadas com diferentes produtos. UFLA, Lavras, MG, 2006.

\begin{tabular}{ll}
\hline Produtos & \multicolumn{1}{c}{ MSR } \\
\hline Testemunha $^{\circledR}$ & $0,0518 \mathrm{~B}$ \\
Stimulate $^{(}$ & $0,0590 \mathrm{AB}$ \\
Cellerate 1 & $0,0603 \mathrm{AB}$ \\
Cellerate 2 & $0,0617 \mathrm{~A}$ \\
\hline
\end{tabular}

As médias seguidas pela mesma letra não diferem entre si, pelo Teste de Tukey, a 5\% de probabilidade.

TABELA3. Massa seca de parte aérea (MSPA) das plântulas de híbrido de milho oriundas de sementes tratadas em duas épocas. UFLA, Lavras, MG, 2006.

\begin{tabular}{lc}
\hline Épocas & MSPA \\
\hline Antes do armazenamento & $0,0551 \mathrm{~A}$ \\
Pré-semeadura & $0,0521 \mathrm{~B}$ \\
\hline
\end{tabular}

As médias seguidas pela mesma letra não diferem entre si, pelo Teste de Tukey, a 5\% de probabilidade. 


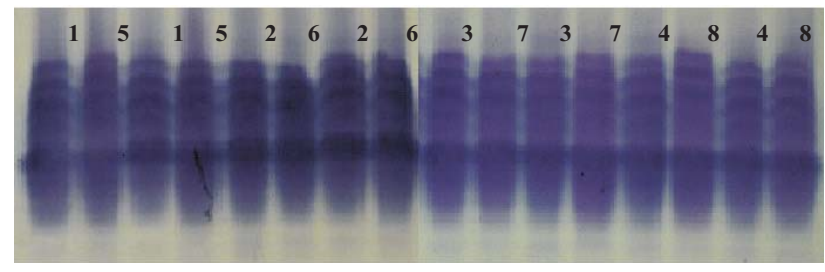

MDH

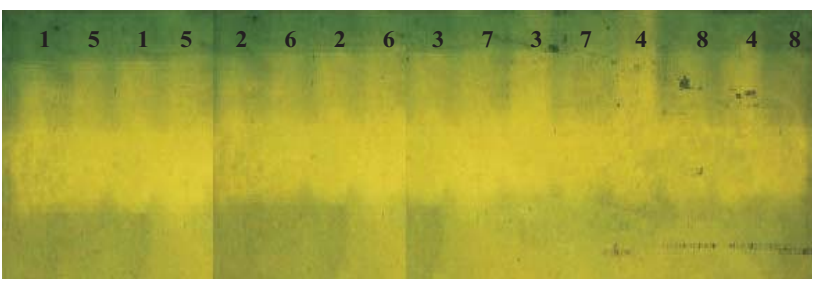

CAT

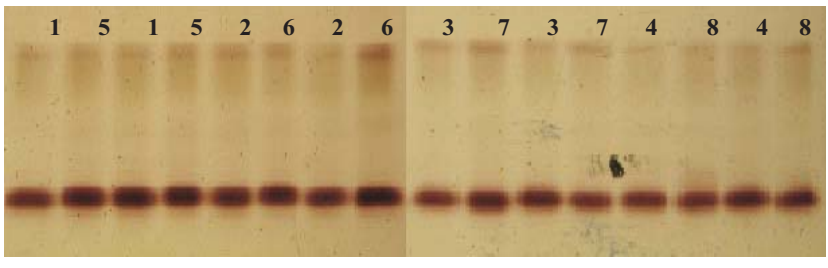

EST

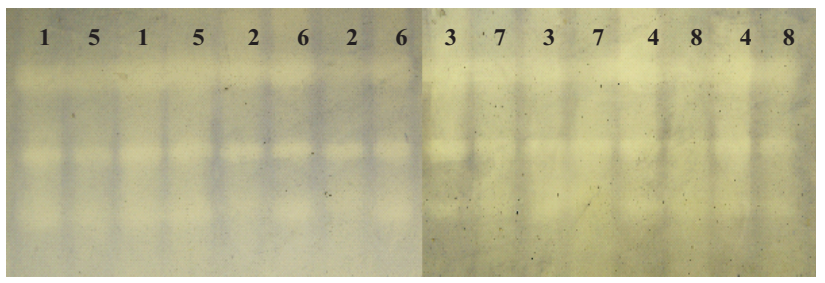

SOD

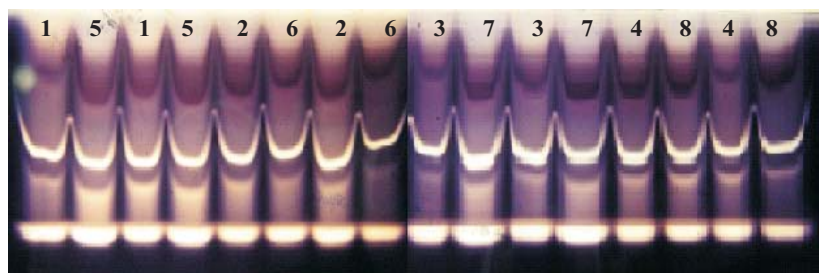

\section{$\boldsymbol{\alpha}-\mathbf{A M}$}

1 e 5: Testemunha; 2: Stimulate ${ }^{\circledR}$,seis meses antes da semeadura; 6: Stimulate ${ }^{\circledR}$,na pré-semeadura; 3: Dose 1 de Cellerate ${ }^{\circledR}$,seis meses antes da semeadura; 7: Dose 1 de Cellerate ${ }^{\circledR}$,na pré-semeadura; 4: Dose 2 de Cellerate ${ }^{\circledR}$, seis meses antes da semeadura; 8: Dose 2 de Cellerate ${ }^{\circledR}$,na pré-semeadura.

FIGURA 2. Padrões enzimáticos de sementes do híbrido de milho tratadas com diferentes produtos, seis meses antes da semeadura e na pré-semeadura, revelados para malato desidrogenase (MDH), esterase (EST), catalase (CAT), superóxido dismutase (SOD) e á-amilase (á-AM). UFLA, Lavras, MG, 2006.

sementes.

A atividade da esterase foi maior nas sementes que receberam a maior dose de Cellerate ${ }^{\circledR}$ antes do período de armazenamento (6 meses) (Figura 2). A esterase é uma enzima que participa da hidrólise de ésteres. Trabalhando com sementes de soja, Shatters et al. (1994), observaram aumento da atividade total dessa enzima com o envelhecimento.

Por meio padrões eletroforéticos das enzimas catalase (CAT) e superóxido dismutase (SOD) de sementes tratadas com a maior dose de Cellerate ${ }^{\circledR}$ e armazenadas por seis meses, foi observada maior atividade dessas enzimas em relação às das sementes tratadas na pré-semeadura (Figura 2). Provavelmente os micronutrientes presentes no produto tenham causado algum efeito fitotóxico às sementes, levando à produção de superóxido, caracterizada pela maior atividade da enzima superóxido dismutase (Figura 2); desse modo o mecanismo "scavenger" foi ativado durante a embebição das sementes para “retirar” o peróxido de hidrogênio produzido. As enzimas capazes de realizarem a desintoxicação de $\left(\mathrm{O}_{2}^{-}\right)$e $\mathrm{H}_{2} \mathrm{O}_{2}$ são: a superóxido dismutase (SOD), catalase (CAT), glutamato peroxidase (GP) e glutamato redutase (GR) (McDonald, 1999).

As superóxidos dismutase são um grupo de enzimas encontrados no citoplasma celular e matriz mitocondrial. Catalisam a reação de dismutação de radicais superóxidos livres $\left(\mathrm{O}_{2}{ }^{-}\right)$produzidos em diferentes locais na célula, para oxigênio molecular $\left(\mathrm{O}_{2}\right)$ e peróxido de hidrogênio $\left(\mathrm{H}_{2} \mathrm{O}_{2}\right)$. O peróxido de hidrogênio gerado é decomposto principalmente pela catalase, cujas subunidades são formadas no citoplasma, sendo a síntese completada no peroxissomo. Em outros compartimentos subcelulares, o peróxido de hidrogênio é removido pelas peroxidases (McDonald, 1999). Esses resultados ratificam os valores reduzidos da emergência no teste de frio. 
É notável a maior atividade da á-amilase em sementes que foram tratadas com o bioestimulante e armazenadas por seis meses e com a dose 1 de Cellerate ${ }^{\circledR}$ na pré-semeadura (Figura 2). O Stimulate ${ }^{\circledR}$ é composto por quantidades balanceadas dos principais grupos de hormônios, desse modo sua ação sobre o sistema hormonal que desencadeia a produção "de novo" da á-amilase pode ter influenciado nessa maior atividade observada. No início da hidratação, enzimas hidrolíticas, tais como: amilases, proteinases e â-glucanases tornam-se ativadas no embrião. Em cereais, a atividade da amilase é essencial para fornecer energia e esqueleto carbônico para o embrião se desenvolver, por meio da quebra respiratória de substratos utilizáveis. As enzimas a e b-amilases estão envolvidas no principal sistema de degradação de amido das sementes.

Avaliação da qualidade fisiológica das sementes da linhagem de milho

Pelos resultados da análise de variância dos dados obtidos de sementes da linhagem de milho, foi observada diferença significativa $(\mathrm{p}<0,05)$, pelo teste de $\mathrm{F}$, para a interação produtos $\mathrm{x}$ épocas de tratamento para os parâmetros germinação e emergência pelo teste de frio; já para a massa seca de parte aérea e de raiz das plântulas, houve diferença significativa apenas para o fator produtos.

Pelos resultados da Tabela 4, houve redução na germinação e na emergência de plântulas, no teste de frio, quando as sementes foram tratadas na pré-semeadura com a maior dose do produto Cellerate ${ }^{\circledR}$; já para aquelas que foram tratadas e armazenadas por seis meses, não houve redução nos valores de germinação e emergência. Provavelmente, durante o armazenamento, houve degradação de algum componente do Cellerate ${ }^{\circledR}$ que é tóxico às sementes.

A massa seca de raiz foi incrementada com o tratamento das sementes com o bioestimulante e com o fertilizante em relação à testemunha não tratada (Tabela 5). Já a massa seca de parte aérea, foi maior apenas para as plântulas oriunda de sementes tratadas com a dose 1 de Cellerate ${ }^{\circledR}$. Resultados semelhantes foram encontrados por Vieira (2001), quando foram testadas diferentes doses do bioestimulante em tratamento de sementes de milho e soja.

Avaliação dos padrões enzimáticos das sementes da linhagem de milho

Pela análise dos sistemas enzimáticos malato desidrogenase (MDH) e álcool desidrogenase (ADH), notase uma redução na atividade da MDH em sementes tratadas em pré-semeadura com a maior dose de Cellerate ${ }^{\circledR}$ (Figura 3) e ainda, um aumento da atividade da ADH (Figura 3), o que sugere uma respiração anaeróbica dessas sementes, provavelmente em função da fitotoxidez causada pelo produto às mesmas. $\mathrm{A} A D H$ é uma enzima que atua no processo respiratório, removendo substâncias tóxicas às sementes, como acetaldeído e etanol, que são produzidos quando as células passam a respirar anaerobicamente (Faria et al., 2003). Esse efeito fitotóxico também foi observado nos testes de germinação e de frio, nos quais foram observados menores valores de germinação e emergência de plântulas, quando o tratamento foi realizado na pré-semeadura. Durante o armazenamento deve ter ocorrido degradação de algum componente do produto.

Para o sistema enzimático catalase, foi observada maior atividade em sementes tratadas seis meses antes da semeadura com a maior dose de Cellerate ${ }^{\circledR}$ (Figura 3), assim como o observado para o híbrido. Já para as sementes tratadas com o Stimulate ${ }^{\circledR}$ na pré-semeadura, houve aumento na atividade da esterase (EST) e da superóxido dismutase (SOD) (Figura 3).

Assim como o que ocorreu para as sementes híbridas, houve uma maior atividade da á-amilase nas sementes da linhagem de milho tratadas com o bioestimulante, no entanto, esse aumento da atividade ocorreu nas sementes tratadas na pré-semeadura (Figura 3). Tais resultados comprovam a ação do bioestimulante sobre o sistema hormonal das sementes, pois a á-amilase é sintetizada pela ação das giberelinas que induzem o gene para á-amilase (Marcos Filho, 2005).

TABELA 4. Porcentagem de germinação e emergência em teste de frio de plântulas de linhagem de milho oriundas de sementes tratadas com diferentes produtos em duas épocas. UFLA, Lavras, MG, 2006.

\begin{tabular}{lcccc}
\hline \multirow{2}{*}{ Produtos } & \multicolumn{2}{c}{ Germinação } & \multicolumn{2}{c}{ Emergência } \\
\cline { 2 - 5 } & 6 meses antes da semeadura & Pré-semeadura & 6 meses antes da semeadura & Pré-semeadura \\
\hline Testemunha $^{\circledR}$ & $91,0 \mathrm{aA}$ & $97,0 \mathrm{aA}$ & $88,5 \mathrm{aA}$ & $90,5 \mathrm{aA}$ \\
Stimulate $^{(}$ & $92,0 \mathrm{aA}$ & $90,0 \mathrm{aA}$ & $92,0 \mathrm{aA}$ & $91,5 \mathrm{aA}$ \\
Cellerate 1 & $91,5 \mathrm{aA}$ & $92,5 \mathrm{aA}$ & $89,0 \mathrm{aA}$ & $90,5 \mathrm{aA}$ \\
Cellerate 2 & $92,0 \mathrm{aA}$ & $71,5 \mathrm{bB}$ & $87,0 \mathrm{aA}$ & $79,0 \mathrm{bB}$ \\
\hline
\end{tabular}

As médias seguidas pela mesma letra não diferem entre si, pelo Teste de Tukey, a 5\% de probabilidade. 


\section{Experimentos em campo \\ Híbrido}

Houve diferença significativa $(\mathrm{p}<0,05)$, pelo teste de $\mathrm{F}$, apenas para o parâmetro altura de espiga em relação à interação produtos x épocas de tratamento (Tabela 6). Quando as

TABELA5. Massa seca de parte aérea (MSPA) e de raiz (MSR) de plântulas de linhagem de milho oriundas de sementes tratadas com diferentes produtos. UFLA, Lavras, MG, 2006.

\begin{tabular}{lll}
\hline Produtos & MSPA & MSR \\
\hline Testemunha $^{\circledR}$ & $0,0409 \mathrm{~B}$ & $0,0465 \mathrm{~B}$ \\
Stimulate $^{(}$ & $0,0434 \mathrm{AB}$ & $0,0535 \mathrm{~A}$ \\
Cellerate 1 & $0,0453 \mathrm{~A}$ & $0,0543 \mathrm{~A}$ \\
Cellerate 2 & $0,0430 \mathrm{AB}$ & $0,0529 \mathrm{~A}$ \\
\hline
\end{tabular}

As médias seguidas pela mesma letra não diferem entre si, pelo Teste de Tukey, a 5\% de probabilidade.

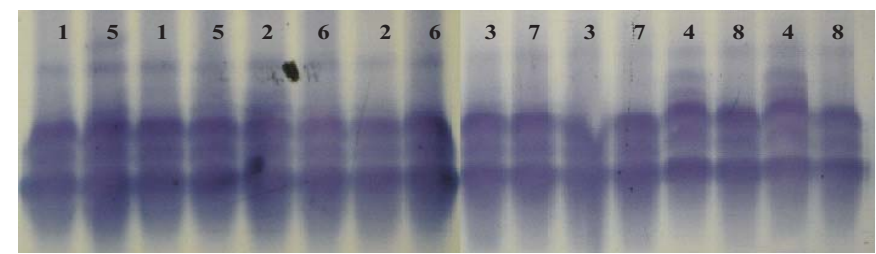

MDH

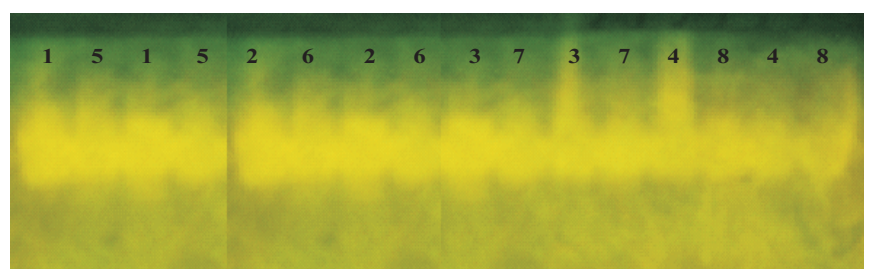

CAT

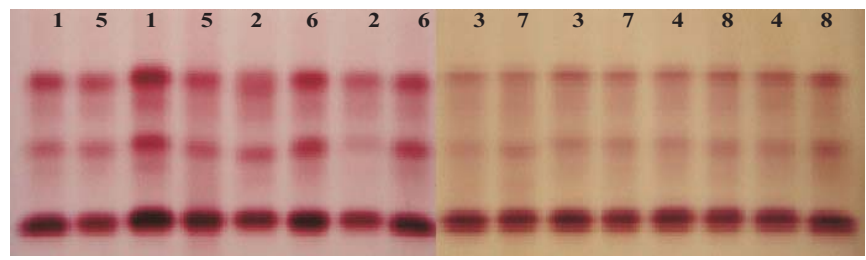

EST sementes foram tratadas com os produtos, Stimulate ${ }^{\circledR} \mathrm{e}$ Cellerate ${ }^{\circledR}$, na pré-semeadura, foi observado maior desenvolvimento das plantas e conseqüentemente maior altura de espigas.

Para os demais parâmetros avaliados, estande final, número de espigas e produtividade, não foram observadas diferenças significativas entre os tratamentos avaliados. Resultados semelhantes foram encontrados por Dário e Baltieri (1998) quando aplicaram o Stimulate ${ }^{\circledR}$ em tratamento de sementes de milho.

\section{Linhagem}

Foi observada diferença significativa ( $\mathrm{p}<0,05$ ), pelo teste de F, para a altura de planta e de espiga, em relação à interação produto x época de aplicação. Em plantas oriundas de sementes tratadas com a menor dose de Cellerate ${ }^{\circledR}$, seis meses antes da semeadura, foi observada menor altura e

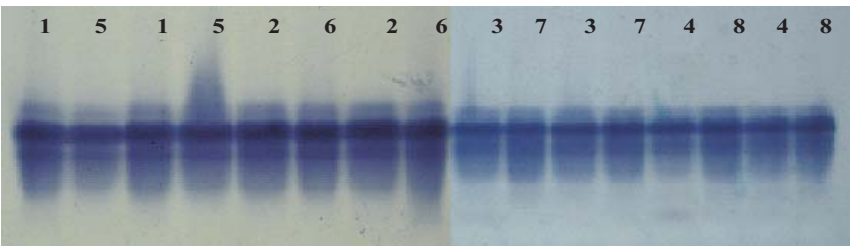

ADH

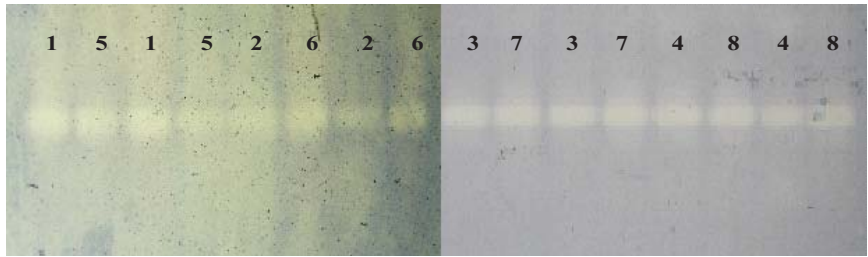

SOD

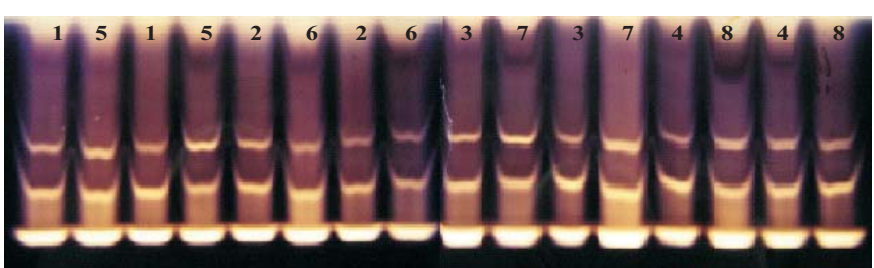

$\boldsymbol{\alpha - A M}$

1 e 5: Testemunha; 2: Stimulate ${ }^{\circledR}$,seis meses antes da semeadura; 6: Stimulate ${ }^{\circledR}$,na pré-semeadura; 3: Dose 1 de Cellerate ${ }^{\circledR}$, seis meses antes da semeadura; 7: Dose 1 de Cellerate ${ }^{\circledR}$,na pré-semeadura; 4: Dose 2 de Cellerate ${ }^{\circledR}$,seis meses antes da semeadura; 8: Dose 2 de Cellerate ${ }^{\circledR}$,na pré-semeadura.

FIGURA 3. Padrões enzimáticos de sementes de linhagem de milho tratadas com diferentes produtos, seis meses antes da semeadura e na pré-semeadura, revelados para malato desidrogenase (MDH), esterase (EST), catalase (CAT), superóxido dismutase (SOD) e á-amilase (á-AM). UFLA, Lavras, MG 2006. 
conseqüentemente menor altura de espiga (Tabela 7). Esse efeito do produto sobre o desenvolvimento das plantas de milho pode ter ocorrido em função de fitotoxidez causada por algum dos elementos presentes no produto. No entanto, a produtividade final não foi afetada pelo produto utilizado.

Para a produtividade, número de espigas e número de plantas não houve diferença significativa entre os tratamentos, resultado semelhante ao experimento com o híbrido.
TABELA 6. Altura de espiga (AE) das plantas de híbrido de milho oriundas de sementes tratadas em duas épocas. UFLA, Lavras, MG, 2006.

\begin{tabular}{lc}
\hline Épocas & AE \\
\hline 6 meses antes da semeadura & $113,05 \mathrm{~B}$ \\
Pré-semeadura & $115,98 \mathrm{~A}$ \\
\hline
\end{tabular}

As médias seguidas pela mesma letra não diferem entre si, pelo Teste de Tukey, a 5\% de probabilidade.

TABELA 7. Altura de planta (AP) e altura de espiga (AE) de linhagem de milho oriundas de sementes tratadas com diferentes produtos em duas épocas. UFLA, Lavras, MG, 2006.

\begin{tabular}{lcccc}
\hline \multirow{2}{*}{ Produtos } & \multicolumn{2}{c}{ AP } & \multicolumn{2}{c}{ AE } \\
\cline { 2 - 5 } & 6 meses antes da semeadura & Pré-semeadura & 6 meses antes da semeadura & Pré-semeadura \\
\hline Testemunha $_{\text {Stimulate }}{ }^{8}$ & $162,93 \mathrm{aA}$ & $155,63 \mathrm{bB}$ & $72,00 \mathrm{aA}$ & $70,83 \mathrm{aA}$ \\
Cellerate 1 & $160,25 \mathrm{aA}$ & $159,08 \mathrm{aAB}$ & $74,20 \mathrm{aA}$ & $71,35 \mathrm{aA}$ \\
Cellerate 2 & $150,73 \mathrm{bB}$ & $159,30 \mathrm{aAB}$ & $66,33 \mathrm{bB}$ & $70,80 \mathrm{aA}$ \\
\hline
\end{tabular}

As médias seguidas pela mesma letra não diferem entre si, pelo Teste de Tukey, a 5\% de probabilidade.

\section{CONCLUSÕES}

O tratamento das sementes de milho com o Cellerate ${ }^{\circledR}$, na dose de $10 \mathrm{ml} . \mathrm{kg}^{-1}$ de sementes, acima da dose recomendada pelo fabricante, reduz a emergência de plântulas de milho de linhagem e de híbrido e a germinação de sementes de linhagem, quando o tratamento é feito na pré-semeadura.

O tratamento das sementes de milho com o bioestimulante Stimulate ${ }^{\circledR}$ e com o fertilizante Cellerate ${ }^{\circledR}$ não afeta a produtividade de grãos.

\section{REFERÊNCIAS}

ALFENAS, A. C.; PETERS, I.; BRUNE, W; PASSADOR, G. C. Eletroforese de proteínas e isoenzimas de fungos e essências florestais. Viçosa, UFV, 242p., 1991

ALLEONI, B. Efeito do regulador vegetal Stimulate no desenvolvimento e produtividade do feijoeiro (Phaseolus vulgaris L.). Ponta Grossa: Universidade Estadual de Ponta Grossa, 1997. 15p. (Relatório Técnico).

BELMONT Ação de fitorregulador de crescimento na germinação de sementes de algodoeiro. Areia: Centro de Ciências Agrárias/ UFPB, 2003. 48p. (Relatório de Pasquisa).

BRASIL. Ministério da Agricultura e da Reforma Agrária. Regras para análise de sementes. Brasília: SNDA/DNDV/CLAV, 1992. 365 p.

CASTRO, P. R. C.; KLUGE, R. A. Ecofisiologia de cultivos anuais. São Paulo: Nobel, 1999. 126p.

CASTRO, P.R.C.; VIEIRA, E.L. Aplicações de reguladores vegetais na agricultura tropical. Guaíba: Agropecuária, 2001. 132p.

DARIO, G. J. A.; BALTIERI, E. M. Avaliação da eficiência do regulador vegetal Stimulate (citocinina + ácido indolbutírico + ácido giberélico) na cultura do milho (Zea mays L.). Piracicaba: ESALQ/USP, 1998. 12p. (Relatório Técnico).

FARIA, L.C., COSTA, J.G.C., RAVA, C.A., PELOSO, M.J.D., MELO, L.C., CARNEIRO, G.E.S., SOARES, D.M., DÍAZ, J.L. C., ABREU, A.F.B., FARIA, J.C., SARTORATO, A., SILVA, H.T., BASSINELLO, P.Z. \& ZIMMERMANN, F.J.P. BRS Requinte: nova cultivar de feijoeiro comum de tipo de grão carioca com retardamento do escurecimento do grão. 1.ed. Comunicado Técnico, 65. Santo Antônio de Goiás, GO. EMBRAPA Arroz e Feijão. 2003.

FERREIRA, D.F. Análises estatísticas por meio do SISVAR para Windows $^{\circledR}$ versão 4.0. In: REUNIÃO ANUAL DA REGIÃO BRASILEIRA DA SOCIEDADE INTERNACIONAL DE BIOMETRIA, 45., 2000, São Carlos, SP. Programas e Resumos... São Carlos: UFSCar, 2000. p. 235.

INTERNATIONAL SEED TESTING ASSOCIATION - ISTA Handbook of vigor test methods. 3ed. Zürich: ISTA. 1995. 117p.

Mc DONALDL, M. B. Seed deterioration: physiology, repair and assessment. Seed Science and Technology, Zürich, v. 27, p. 177237, 1999.

MARCOS FILHO, J. Fisiologia de plantas cultivada. Piracicaba: FEALQ, 2005. 496 p.

MAGUIRE, J. D. Speed of germination aid in selection and evaluation for seedling and vigour. Crop Science, Madison, v.2, n.2, p. 176-177, 1962.

ONO, E.O.; RODRIGUES, J.D.; SANTOS, S.O. Efeito de fitorreguladores sobre o desenvolvimento de feijoeiro (Phaseolus vulgaris L.) cv Carioca. Revista Biociências, Taubaté, v.5, n.1, p.7-13, 1999. 
SHATTERS, R. G. J. R.; ABDELGHANY, A.; ELBAGOURY, O. Soybean seed deterioration and response to priming: changes in specific enzyme activities in extracts from dry and germinating seeds. Seed Science Research, Wallingford, v.4, n.1, p. 33-41, 1994.

TAIZ, L.; ZEIGER,E. Plant physiology. Redwood City: The Benjamin/Cummings, 1991. 559 p.

VIEIRA, E. L. Ação de bioestimulante na germinação de sementes, vigor de plântulas, crescimento radicular e produtividade de soja
(Glycine max (L.) Merrill), feijoeiro (Phaseolus vulgaris L.) e arroz (Oryza sativa L.). 2001. 122f. Tese (Doutorado em ?) Escola Superior de Agricultura “Luiz de Queiroz”, Universidade de São Paulo, Piracicaba, 2001.

VIEIRA E. L.; CASTRO. P.R.C. Ação do Stimulate na germinação de sementes, vigor de plântulas e crescimento radicular de plantas de milho (Zea mays L.). Piracicaba: ESALQ/USP, 2000. 15p. (Relatório Técnico). 